\title{
Family Business Succession of SMEs and Post-Transition Business Performance
}

\author{
Nor Aishah Buang ${ }^{1}$ Ganefri $^{2} \&$ Saliza Sidek ${ }^{1}$ \\ ${ }^{1}$ Faculty of Education, Universiti Kebangsaan Malaysia, Selangor, Malaysia \\ ${ }^{2}$ Universitas Negeri Padang, Indonesia \\ Correspondence: Nor Aishah Buang, Faculty of Education, Universiti Kebangsaan Malaysia, 43600 UKM Bangi, \\ Selangor, Malaysia. E-mail: noraishah1962@gmail.com
}

Received: August 1, 2013 Accepted: August 16, 2013 Online Published: August 30, 2013

doi:10.5539/ass.v9n12p79 URL: http://dx.doi.org/10.5539/ass.v9n12p79

\begin{abstract}
This study aimed at identifying the relationship between the success factors of succession in terms of preparation of heirs, the relationship between family and business as well as planning and control activities to smooth transition process. In addition, the smoothness of the transition process was also studied to determine its relationship with post-transition performance. This study included 70 of the successors of family business around Kuala Terengganu which are selected as study samples. Data was analyzed using SPSS 18.0. Contingency coefficient test, Pearson $r$ correlation and Spearman rho is used to measure the relationship between the variables of the study. The results showed the entry-level position and the relationship between family and business have significant influence on the smoothness of the transition process. While the planning and control has no significant relationship with the smoothness of the transition process. The study also shows the smooth process of transition has no significant influence on post-transition performance. The study is expected to help SMEs family business implement an effective succession process to develop future heirs and sustain the business in the market for a long time.
\end{abstract}

Keywords: family business, succession, transition, post-transition performance

\section{Introduction}

Family business plays a key role and become the backbone of a country's economic growth (Jasani, 2002; Chua et al., 2003; Poza, 2004; Hemalatha, 2010). In Malaysia, the family business contributes more than half of the Gross Domestic Product (GDP) (Ngui, 2002). Family business-related studies showed that more than 90 percent of the businesses that exist in democratic countries is a family business (McCann et al., 2001; Davis \& Harveston, 2001; Voithofer \& Mandl, 2004).

Studies on the family business in Malaysia showed 70 percent of businesses owned and controlled by families (Claessens et al., 2000) and inherited from their own descendants (Rahman, 2006). Most of the family business in Malaysia is small (51 employees and below) are still managed by the founder of which is focused on manufacturing activity, retail or construction (Hemalatha, 2010). Similarly, studies Jasani (2002), revealed that the family business in Malaysia consists of 55 per cent of small enterprises, 35 per cent and 10 per cent of medium enterprises large scale. For small and medium enterprises (SMEs), 65 percent were still managed by the founder himself, especially those involved in trade, manufacturing and retail. Many businesses started by traders who already have work experience of more than six and a half years.

In an effort to expand the family business into a strong and successful business, all members need to develop the business practices and a certain philosophy and maintaining a good balance between family and business (Gomez, 2005). This is because one of the main factors determining the success of a family business is the ability to maintain the relationship between family and business through the changes and managed to pass through a long period (Sheetal, 2006). Thus the development of the succession process is an important factor in determining the success of family business sustainability. In addition, effective succession process allows families and businesses continue to prosper and to meet future claims with (Carlock \& Ward, 2005). According Sigalas et al. (2008), due to closure of the family firm succession process is not effective to give serious implications not only to family members and non-family employees, but also to the economic development of 
the area and the overall economy in general.

\section{Statement of the Problem}

Jasani (2002) study on the family business in Malaysia showed 59 percent of family businesses run by the founder, only 30 percent managed by second generation and most inherited by the sons of the founder. Similarly, studies on SMEs in 27 countries also found that 75 percent controlled by the founder of the family business, 30 percent could be forwarded to the second generation and only 10 percent could be forwarded to the third generation (Sreih et al., 2008). According to Le Breton Miller et al. (2004), when the owner retired, less than third-generation family business continues to the second, while less than half of the second generation will continue to the third generation. These findings proved the ability of the family business to survive in the market for a long period is difficult. In studies related to the family business, the key factor that is often a challenge in order to maintain the family business succession issues (Yong, 2002; Sharma, 2003; Chua, 2003; Pyromalis et al., 2006; Lam, 2009; Moha Asri et al., 2011; Brenes et al., 2011).

In Malaysia, although the SME family business among the largest contributors to economic growth (Noor Afza, 2011; Moha Asri et al., 2011) and employment opportunities (Yong, 2006), but family businesses face the threat of competition from within his own family business, especially about succession issues (Norita et al., 2010). Succession issues is one of the critical issues, particularly relating to the effectiveness of the succession (Ibrahim, 2001), and smooth business transition process (Morris et al., 1996; Wang et al., 2006; She \& Ahmad Najmi, 2009). Throughout the world, statistics on the success of the succession process in family businesses is worrying (Poutziouris, 2001; Ibrahim, 2001).

Although there are many studies related to succession, but the emphasis on preparation of heirs are less concern when it is an important aspect of the succession process (Sardeshmukh, 2008). In the whole process of succession, to achieve effective guidance, the owner should consult the guidance of the succession process at an earlier stage (Wang et al., 2004), when the business is still in control (Jasani, 2002). This is because the key to the effectiveness of the succession is getting the optimal guidance in a timely manner from their parents (Carlock, 2010). According Smyrnios \& Dana (2006), the key factor to the problems the family business is related to the founder or owner. The owner refused to give up his business is the lack of preparedness to give management control to the next generation (Sharma et al., 2001, Norria, 2007). Therefore, most businesses have a strong but ultimately failed because there is no plan to continue their business to the successor (Parish, 2009).

Although many studies have been conducted on entrepreneurship and SMEs in Malaysia, but the study of family business is still lacking (Moha Asri et al., 2011; Noor Afza et al., 2009). Jasani (2002) study briefly discussed the succession planning, but the study only provides a brief review of current practices in the family succession, without analyzing the impact of succession planning and other succession issues on the financial performance of business (Noor Arfa \& Ayoib, 2009). While overseas studies related business performance shows the performance of family businesses are better than non-family businesses (Bocatto, 2005; Zahra et al., 2004; Chua et al., 2003; McConaughy, 2000), but the returns generated by the family business absorbed by inefficiencies related to the family (Schulze, 2003). Various factors driving the family business can not last long. Therefore, to ensure the success factors of succession, such as preparation level of heirs, the relationship between family and business, planning and control needs to be done to identify the relationship of each of these factors with the smooth transition and subsequent effects on post- transition performance.

\subsection{Family Business Succession}

According to Handler (1994), succession is not just a single transfer of a baton, but it involves various levels of time-consuming process and most start before the successor enters the business. Succession is not only limited effectiveness if the president has been set, but it includes continuous business soundness, quality of life and family dynamics.

Handler (1990) agree that the factors that influence the effectiveness of the succession is the level of training, responsibility, experience outside the organization, communication of relevant succession and succession planning. According to Venter et al. (2005), two main factors that influence the success of the succession process is the successor satisfaction with the experience they went through the process of succession and family business profits continued after the succession. According to Morris et al. (1996) previous studies on the succession process has identified several factors related to effectiveness transition. These factors are divided into three categories, preparation level of heirs, the relationship between family and business as well as planning and control activities as in Table 1. 
Table 1. Transition success factors

\begin{tabular}{llll}
\hline Preparation level of heirs & \multicolumn{2}{l}{ The relationship among family and } & Planning and control activities \\
& business members & \\
\hline - Formal education & - Communication & - Succession planning \\
- Training & - Trust & - Tax Planning \\
- Work experience & - Commitment & Use of outside board \\
(outside firm) & - Loyalty & Consultant / advisors \\
- Entry-level position & - Family turmoil & Creation of a family council \\
- Year working within & - Sibling rivalry & \\
firm & - Jealousy / resentment & \\
- Motivation to join firm & - Conflict & \\
- Self-perception of & - Shared values and traditions & \\
preparation & &
\end{tabular}

Source: Morris et al. (1996)

The first category is the preparation level of heirs. According to Longenecter et al. (2005), a family business sustainability depends on the availability of capable successors. This is because the generic knowledge and skills acquired through formal education can be used in many business contexts (Sardershmukh \& Corbett, 2011) and enables them to identify business opportunities and implement them (Robinson \& Sexton 1994 and Dickson et al. 2008). In addition, according Sardeshmukh (2008), heir development process is also closely linked with the experience of working with family businesses. Work experience is important for the future heirs to increase life expectancy family business (Kuratko \& Hodget, 2006; Reijonen \& Kommpula, 2007; Song et al., 2008; Umar Haiyat, 2010) and a positive impact on business success (Luke, 1996; Masuo et al., 2001; Ucbasaran et al., 2010). Work experience outside the family business is considered a strong asset to the heirs in which the most thriving heirs have lot of experience working in other companies and other jobs (Barach \& Gantinsky, 1995). It is important to involve the heirs in the business as early as possible. This allows them to learn the business operations from the ground which will give them the experience and commitment to the business. It can be done by providing job training (Sardeshmukh, 2008).

From the aspect of the relationship among family and business members, according to Bachkaniwala et al. (2001), good relationships between family members is a key determinant in maintaining the harmony of the next business can achieve a successful transition. Family members have to work hard and help maintain a consensus within the organization. Family businesses can enjoy the competitive advantage of the strong form of reliability if they can leverage the trust of each other starting from the early stages of a family business (Carlock \& Ward, 2001). However, if the basis of this trust is not supported by structures and processes that promote efficiency and system reliability, then the trust between each other is unlikely to survive in the long run (Sundaramurthy, 2008). Similarly, in the process of succession, through positive communication of all the conflict and competition that will have negative effects on business succession inevitable. This shows the positive relationship that exists between a good relationship with the communication will affect the effectiveness of the succession process (Plyromalis \& Vozikis, 2009).

While the third category is the planning and control activities. Sharma et al. (2003) study showed that the ability to resolve conflicts between family members, competition, inefficiency, democratic leadership depends on planning and control activities in the family business. Other studies also showed the main factors that determine a family business can continue from one generation to another is succession planning (Demers, 2003; White et al., 2004; Wang et al., 2004; Ip \& Jacobs, 2006; Coleman \& Greig, 2009). Succession planning is a dynamic process that demands ownership and management to plan a family business in the future (Dyck, 2002; Sharma, 2003). According to Morris et al. (1997), a preoccupation with avoiding taxation may find the owner or manager ignoring fundamental business issues. It is important that tax planners try to help family business owners to think as a whole by helping owners to understand that tax planning is not a substitute for succession planning.

\subsection{Methodology}

This study is a survey study. Researchers have selected a stratified random sampling as the sampling design. 
Population studies of family businesses small and medium enterprises (SMEs) that have been handed over power management to the successors are 85 people. While this sample consists of 70 family business managers of small and medium enterprises (SMEs) in Kuala Terengganu which has undergone at least one transition. Sample selection is based on the formula and the determination of sample size by Krejcie \& Morgan (1970).

The questionnaire consists of seven parts, part A of the demographic traders / entrepreneurs, business demographic information part $\mathrm{B}$, part $\mathrm{C}$ of the preparation of heirs, part $\mathrm{D}$ of the planning and control activities, part $\mathrm{E}$ is the relationship between family and business, part $\mathrm{F}$ includes the characteristics of the transition and part $\mathrm{G}$ of post- transition business performance. Instrument for the $\mathrm{C}, \mathrm{D}, \mathrm{E}$ and $\mathrm{F}$ are adapted based on the findings of the Morris et al (1996) study, while part $G$ an adaption of the Sheetal (2006)questionnaires.

Scale of measurement in this study is comprised of a variety of nominal scale, ordinal and five-point likert. Part $\mathrm{A}, \mathrm{B}$, and $\mathrm{D}$, all items are measured using a nominal scale, while the $\mathrm{C}$ using the scale of measurement nominal, ordinal and likert five-point. All items in the E measured using five-point likert scale. Part $\mathrm{F}$ is to use of measurement five-point likert scale and nominal. While the $\mathrm{G}$ using an ordinal scale of measurement. Five-point likert scale used strongly disagree (1), disagree (2), less agree (3), agree (4) and strongly agree (5).

A pilot study shows the value of Cronbach Alpha for the overall dimensions of the relationship between family and business is 0.813 , while for the aspect of the smooth transition process is 0.793 .

Survey data collected using a questionnaire was analyzed using SPSS program (Statistical Package For Social Science version 18.0). Two types of statistics used in the descriptive statistics and inferential statistics. Data analyzed using the descriptive statistical studies such as frequency and percentage for distribution profile in terms of preparations of heirs, planning and control activities, characteristic of the transition and post-transition performance of the SME family business. Furthermore, descriptive statistics such as mean and standard deviation are used to identify the relationship between family and business as well as the level of smoothness of the transition process of SME family business. Interpretation of mean scores by Nunnally and Bernstein (1994) as in Table 2 are used to determine the level of variables of this study.

Table 2. Mean score interpretations

\begin{tabular}{ll}
\hline Score Mean & Level \\
\hline 1:00 to $2: 00$ & Low \\
2:01 to $3: 00$ & Medium Low \\
3:01 to $4: 00$ & Medium \\
4:01 to $5: 00$ & High \\
\hline
\end{tabular}

Source: Nunnally and Bernstein (1994)

Inferential statistical analysis was used to test hypotheses and identify the relationships that exist between variables. For the nominal and ordinal scale, data does not have a normal distribution, then the non-parametric tests used. According to Pallant (2007) and Ananda (2009), for data that is not the scattered normal and data is nominal and ordinal scale, then it must be analyzed using a set of non-parametric tests. Among the non-parametric tests used in this study were the Contingency Coefficient and Spearman rho correlation test. While the parametric tests used was Pearson $r$ correlation tests to assess normal and scattered data using five-point likert scale as the scale of measurement data.

\section{Findings and Discussion}

The results analysis includes profile of succession in terms of preparedness, planning and control activities, the level of the relationship between family and business, profile and level of smoothness of the transition process and the post-transition business performance.

\subsection{Preparation of Heirs}

Distribution of preparation of heirs profile is shown in Table 3. The study showed that most heirs have secondary school education level or SPM representing the largest percentage of 58.6 percent. Before taking over the family business management, 27.1 per cent heirs experience working with family businesses is less than one year and between one and five years respectively. Most of them involved in the family business began with the initial stage. A total of 45.7 per cent them motivated to participate due to family business obligation, followed by career 
opportunities and control. From the dimensions of encouragement from the previous generation, the findings showed 38.6 percent of the previous generation to encourage heirs to engage in the family business. While the dimensions of self-perception of preparation, many of them are at very well-prepared to take over their family business.

Table 3. Distribution of preparation level of heirs

\begin{tabular}{|c|c|c|c|}
\hline Dimensions of Preparation of Heirs & Information & Frequency & Percent \\
\hline \multirow[t]{5}{*}{ Formal Education } & Primary School & 10 & 14.3 \\
\hline & Secondary Schools & 41 & 58.6 \\
\hline & Certificate & 7 & 10.0 \\
\hline & Diploma & 7 & 10.0 \\
\hline & Degree & 5 & 7.1 \\
\hline \multirow[t]{5}{*}{ Work experience outside firm } & None & 60 & 85.7 \\
\hline & $1-3$ years & 4 & 5.7 \\
\hline & 4-6 years & 2 & 2.9 \\
\hline & $7-10$ years & 2 & 2.9 \\
\hline & Over 10 years & 2 & 2.9 \\
\hline \multirow[t]{5}{*}{ Year working within firm } & Less than 1 year & 19 & 27.1 \\
\hline & $1-5$ years & 19 & 27.1 \\
\hline & $6-10$ years & 13 & 18.6 \\
\hline & $11-15$ years & 11 & 15.7 \\
\hline & Over 15 years & 8 & 11.4 \\
\hline \multirow[t]{4}{*}{ Entry-level position } & Entry level & 36 & 51.4 \\
\hline & Low Management & 22 & 31.4 \\
\hline & Middle management & 10 & 14.3 \\
\hline & Seniors management & 2 & 2.9 \\
\hline \multirow[t]{5}{*}{ Motivation to join firm } & Control / experience & 15 & 21.4 \\
\hline & Personal needs & 4 & 5.7 \\
\hline & Career Opportunity & 17 & 24.3 \\
\hline & Obligation & 32 & 45.7 \\
\hline & Satisfaction & 2 & 2.9 \\
\hline \multirow[t]{5}{*}{ Encourage the older generation } & Strongly discouraged & 1 & 1.4 \\
\hline & Not encouraged & 1 & 1.4 \\
\hline & Less encouraged & 5 & 7.1 \\
\hline & Encouraged & 27 & 38.6 \\
\hline & Strongly encouraged & 36 & 51.4 \\
\hline \multirow[t]{5}{*}{ Heir self-perceptions of readiness } & Not at all prepared & 1 & 1.4 \\
\hline & Minimally prepared & 2 & 2.9 \\
\hline & Moderately prepared & 5 & 7.1 \\
\hline & Well prepared & 25 & 35.7 \\
\hline & Very well-prepared & 37 & 52.9 \\
\hline
\end{tabular}




\subsection{Profile of Planning and Control Activities}

The findings shown in the table 4 shows that 37.1 percent of the predecessor is still involved in business management but has handed over power to their heirs. While 31.4 per cent respectively have been taken over entirely by the successors because of the previous generation retired and died. 84.3 percent of family businesses make a formal selection based on the expertise available to their heirs. Overall, the most studied family business succession planning and provide a formal tax representing 80 percent and 52.9 percent respectively. Most of the respondents family business does not involve external board and consultancy services as a mentor outside the family business.

Table 4. Distribution planning and control activity profile

\begin{tabular}{|c|c|c|c|}
\hline Dimension of Planning and Control Activities & Information & Frequency & Percent \\
\hline \multirow[t]{3}{*}{ Takeover when predecessor } & Retired & 22 & 31.4 \\
\hline & Died & 22 & 31.4 \\
\hline & Still involved & 26 & 37.1 \\
\hline \multirow[t]{2}{*}{ Successor chosen by formal criteria } & Yes & 59 & 84.3 \\
\hline & No & 11 & 7.15 \\
\hline \multirow[t]{4}{*}{ Successor selection factors } & Skills & 49 & 70 \\
\hline & Personal & 10 & 14.3 \\
\hline & Motivation & 5 & 7.1 \\
\hline & Conditions & 6 & 8.6 \\
\hline \multirow[t]{2}{*}{ Formal succession planning } & Yes & 56 & 80.0 \\
\hline & No & 14 & 20.0 \\
\hline \multirow[t]{4}{*}{ Extent planning alleviated taxes } & Completely & 7 & 10.0 \\
\hline & Majority & 3 & 4.3 \\
\hline & Fair & 34 & 48.6 \\
\hline & No & 26 & 37.1 \\
\hline \multirow[t]{2}{*}{ Use of outside board } & Yes & 2 & 2.9 \\
\hline & No & 68 & 97.1 \\
\hline \multirow[t]{2}{*}{ Use of consultants/advisors } & Yes & 4 & 5.7 \\
\hline & No & 66 & 94.3 \\
\hline
\end{tabular}

\subsection{The Relationship among the Family and Business Members}

Researchers use the description of the mean score on a scale mean score interpretation by Nunnally and Bernstein (1994) as in table 2 to determine the relationship between family and business. Table 5 shows the overall mean score of family relationships and business level is at a high level $(\mathrm{m}=4: 01)$. In terms of each dimension, the highest mean score is the dimension of commitment and loyalty to the family business $(\mathrm{m}=4.30)$, followed by the dimensions of trust between family and business ie 4.20 . All three of these dimensions are at the highest level; while other dimensions are at a moderate level. This indicates that the relationship between family and business in this studied are good where there is the level of commitment, loyalty and faith in the family. In 
addition, it also shows the studied family businesses comprise less disturbances business family, sibling rivalry, jealousy and can handle and control the conflict between family members.

Table 5. Level of family and business relationships

\begin{tabular}{lccc}
\hline Family and Business Relationship Dimension & Mean & SD & Interpretation \\
\hline Communication & 3.87 & 0.36 & Medium \\
Trust & $4: 20$ & 0.43 & High \\
Commitment & $4: 30$ & 0.44 & High \\
Loyalty & $4: 30$ & 0.42 & High \\
Family turmoil & 3.98 & 0.64 & Medium \\
Sibling rivalry & 3.76 & 0.63 & Medium \\
Jealous & 3.91 & 0.62 & Medium \\
Conflict & 3.71 & 0.64 & Medium \\
Sharing Values and Tradition & 3.78 & 0.52 & Medium \\
The overall mean & $\mathbf{4 : 0 1}$ & & High \\
\hline
\end{tabular}

\subsection{The Characteristics of the Transition}

Table 6 shows the distribution of the transition characteristics. Most of the predecessor ready to give up power as promised which revealed that 82.9 per cent ready to pass their power to a new successor. In the process related to the transfer of power, 90 percent of family businesses do not involve a lawsuit against a family member. In terms of the transition period, after being appointed a successor, most of them will take between 7 to 10 years to fully takeover of the family business and mostly power moves by default.

Table 6. Distribution profile of characteristics family business transition

\begin{tabular}{lccc}
\hline Characteristics of Transition Dimension & Information & Frequency & Percent \\
\hline Predecessor relinquish control when promise & Yes & 58 & 82.9 \\
& No & 12 & 1.17 \\
Lawsuit related to the transfer of power & & & \\
& Yes & 7 & 10 \\
& No & 63 & 90
\end{tabular}

Year passed from being designated as heir to actual takeover

$\begin{array}{ccc}\text { Less than 1 year } & 11 & 15.7 \\ \text { 1-3 years } & 12 & 17.1 \\ \text { 4-6 years } & 9 & 12.9 \\ \text { 70-10 years } & 22 & 31.4 \\ \text { Over 10 years } & 16 & 22.9\end{array}$

Assumption of control involved

$\begin{array}{ccc}\text { Major struggle } & 1 & 1.4 \\ \text { Minor struggle } & 6 & 8.6 \\ \text { By default } & 60 & 85.7\end{array}$

Overall, the mean level of smoothness scores are a family business at a medium level $(\mathrm{m}=3.67)$ as shown in Table 7. The highest mean score is in terms of the transition goes smoothly and coordination $(\mathrm{m}=4: 03)$, which is at a high level. While other aspects are at a medium level. This indicates that the family business succession 
transition process of SMEs in Kuala Terengganu is a smooth and well co-ordinated.

Table 7. Level of smoothness of family business transition

\begin{tabular}{lccc}
\hline The smooth transition dimension & Min & SD & Interpretation \\
\hline Comfortable & 3.81 & 0.73 & Medium \\
Smooth & $4: 03$ & 0.54 & High \\
Difficult & 2.89 & 1.05 & Medium Low \\
Frustrating & 3.91 & 0.68 & Medium \\
Complicated & $3: 03$ & 0.95 & Medium \\
Antagonistic & 3.73 & 0.76 & Medium \\
Well co-ordinate & $4: 03$ & 0.38 & High \\
Enjoyable & 3.94 & 0.63 & Medium \\
The overall mean & $\mathbf{3 . 6 7}$ & $\mathbf{0 . 4 8}$ & Medium \\
\hline
\end{tabular}

\subsection{Post-Transition Business Performance}

Post-transition family business performance is discussed based on the four dimensions of sales growth, profit growth, employee growth and asset growth. The growth rate for each dimension of business performance is a approximate for five years from 2005 to 2010 . Overall, these findings indicate the dimensions of the highest percentages of sales growth, profits and assets are at levels of between 21 to 40 percent; while the highest percentage growth in employees is the dimension between one and 20 per cent. This family business performance of SMEs in Kuala Terengganu is at a good level of business performance. This finding supports the findings of the study of Shankar (2010) which showed more than 50 percent of SMEs in the 77 surveyed had a good level of business performance in the average sales growth of six percent to ten percent within five years. The study also coincided with the First Quarter Survey Report for 2011 on SMEs that have 76 percent of respondents said improved business performance in the third quarter 2010 in terms of sales and profit margin (SME Corp. Malaysia, 2011).

$H_{o}$ 1: There is no significant relationship between the succession of family businesses SMEs with smooth transition process.

$H_{o} 1_{a:}$ There is no significant relationship of preparation of heirs (formal education dimension, entry-level position, work experience outside, working within family businesses, motivation to join the family business, encourage from predecessor and self-perception of preparation) with the smooth transition process.

As the aspect of the preparation of heirs use the measurement scale of nominal and ordinal scale, the researchers used non-parametric statistical tests that test Contingency coefficient (c) and Spearman rho correlation test $\left(\mathrm{r}_{\mathrm{s})}\right.$ to test the relationship between the preparation of heirs with a smooth transition. Overall, the findings of statistical analysis as shown in table 8 shows the dimensions of the seven dimension, the entry-level position only the dimensions that have a significant relationship with the smoothness of the transition process. While the other dimensions does not have significant influence on the smoothness of the transition process of the family business. This means that the heirs, which began with positions at the beginning or early stages will affect the smoothness of the transition process of the family business in which the lower the position held by the heir when the starting job, then the transition will be more easily and smoothly. 
Table 8. Analysis of the correlation test of preparation of heirs with the smooth transition

\section{Preparation of Heir Dimensions}

Formal Education

Entry-level position

Work experience outside the family business

Year working within family businesses

Motivation to joint the family business

Encourage by predecessor

Self-perceptions of preparation

* Significant at level $\mathrm{p}<0.05$ (two-tailed)

This finding is contrary to the study of Morris et al. (1996) which shows the dimensions of experience working with family businesses and self-perception of the preparation have a positive effect on the smooth transition. Similarly, the findings Noor Afza (2010) who found the experience of belonging to the heirs gave the advantage to improve the performance of family businesses. While the study of Noraini \& Ahmad Najmi (2009) found preparation of heirs have low significant influence on the performance of family business.

Contradictory findings may be due to the size and type of family business respondents is different from other studies. Most of these samples consist of small family businesses, the smoothness of the transition process may not be influenced by the preparation of heirs in terms of formal education, experience and self-perception of preparation, compared with samples from other studies (Noor Afza 2010; Noraini \& Ahmad Najmi 2009) involving a large business which is listed company. For larger businesses, the transition may be more complex, requiring a longer period of time and consideration of the preparation of the heir is important in determining the smoothness of the transition process.

$H_{o} 1_{b:}$ There is no significant relationship between family relationships and significant business with a smooth transition.

Researchers using Pearson $r$ correlation test to test the relationship between family and business relationships with smooth transition process. Table 9 shows the Pearson $r$ correlation tests between family and business relationships with smooth transition process, the results of the analysis found that the value $r=0.342, p=0004$. While the correlation of both variables are significant at the level of significance $p<0.05$. Thus the findings indicate null hypothesis $\left(\mathrm{H}_{\mathrm{o}} 7\right)$ is rejected, it means that there is a positive and significant relationship between family relationships and business with a smooth transition process.

Table 9. Analysis of pearson $r$ correlation test for the relationship between family and business with the smooth transition process

\begin{tabular}{lcccc}
\hline & N & r & Significant \\
\hline The relationship between the Family and Business & 70 & 0.342 & $0004 * *$ \\
\hline
\end{tabular}

* Significant at level $\mathrm{p}<0.01$ (two-tailed)

These findings support the study of Morris et al. (1996) that showed significant relationship between family and business relationships with smooth transition. In addition, other studies also found that family and business relationship dimensions have a positive significant relationship with the profit margins for small-scale businesses (Wang et al. 2004) and the performance of family businesses (Noraini \& Ahmad Najmi 2009).

$H_{o} 1_{c}$ : There is no significant relationship between planning and control activities (dimensions of succession and tax planning) with a smooth transition process.

Researchers use the Contingency Coefficient Test to test the relationship between the dimensions of succession and tax planning with a smooth transition process. Contingency coefficient test analysis results shown in table 10 found relationship between the dimensions of succession planning (c $(70)=0479, \mathrm{df}=16, \mathrm{p}>0.05)$ and the dimensions of tax planning $(\mathrm{c}(70)=0501, \mathrm{df}=32, \mathrm{p}>0.05)$ significantly with the smooth transition. Thus the 
findings indicate null hypothesis $\left(\mathrm{H}_{0} 1_{\mathrm{c})}\right.$ is received, that there is no significant relationship between the dimensions of succession and tax planning with a smooth transition.

Table 10. Analysis of contingency coefficient test for succession and tax planning dimensions with the smoothness of transition process

\begin{tabular}{lcccc}
\hline Activity Planning and Control dimensions & N & df & c & Significant \\
\hline Succession Planning & 70 & 16 & 0.479 & 0.184 \\
Tax Planning & 70 & 32 & 0.501 & 0.863 \\
\hline
\end{tabular}

This finding shows that although most of the SME family business in Kuala Terengganu provides a formal plan, but it does not have a relationship with a smooth transition in the family business. This finding supports the findings of Morris et al. (1996 \& 1997) who found no relationship between the formal planning processes with a smooth transition. On the other hand, family businesses do not provide a formal planning a significant impact on the smoothness of the transition process.

In addition, the findings of the study Noraini \& Ahmad Najmi (2009) show the planning and control has no significant influence on business performance, although most businesses implement the form of a formal succession planning. Similarly, the study of Wang et al. (2004) found that succession planning does not have a significant relationship with smaller profit margins. But the study Phan et al. (2005) and Sreih et al. (2008) found that succession planning a significant impact on business performance. Similarly, the study found that planning and control activities have a positive significant relationship with the business life.

$H_{o}$ 2: There is no significant relationship between the smoothness of the transition process with post-transition business performance(the dimensions of the profit growth).

Researchers using the Spearman rho correlation test to test the relationship between the smoothness of the transition process with the dimensions of profit growth. Table 11 shows there is no relationship between the smoothness of the transition $\left(r_{s}=0182, p>0.05\right)$ significantly with growth in profits. These findings thus receive null hypothesis $\left(\mathrm{H}_{0} 2\right)$.

Table 11. Spearman rho correlation test analysis for smooth transition process with profit growth dimension

\begin{tabular}{cccc}
\hline & $\mathbf{N}$ & $\mathbf{r}_{\mathbf{s}}$ & Significant \\
\hline Smooth transition & 70 & 0182 & 0131 \\
\hline
\end{tabular}

This means there is no significant relationship between the smoothness of the transition process with the profit growth dimension. Although family business has a smooth transition process, it has no impact on post-transition business performance. The findings are consistent with the study Morris et al. (1996) who found a smooth transition process does not necessarily give better results to post-transition business performance. Overall these findings support the conceptual framework of Morris et al. (1997).

\section{Summary}

The management of family businesses play an important role in determining the success of the succession process. The smooth succession process requires development aspects of the preparation of heirs, the relationship between family and business as well as informal planning. This is because the findings indicate the higher level of communication between families and businesses in which family members and businesses have the confidence, commitment, loyalty is high, the lack of conflict and sibling rivalry, family business transition process will be smoother. In addition, the transition will be smoother if the planning is done informally. For the preparation of heirs' aspect, successors, which began with the position in the early stages of the transition process will be smoothness. But the smoother transition the family business is not necessarily result in better post-transition business performance. The study also hopes to promote awareness among family business owners on the importance of succession processes are managed effectively and systematically. In addition, the government and related agencies have to play a role in the family business of SMEs by providing programs, seminars or workshops dedicated especially to the heirs of family business SMEs to expand the family business into a global and sustaining a business to the next generation. 


\section{References}

Abdul Rahman, R. (2006). Effective corporate governance. Ed ke-1. Shah Alam: University Publication Centre (UPENA).

Abdullah, M. A., Hamid, Z. A., \& Hashim, J. (2011). Family-owned business: towards a model of succession planning in Malaysia. International Review of Business Research Paper, 7(1), 251-264.

Amran, N. A. (2011a). The effect of owner's gender and age to firm performance: A review on Malaysian public listed family businesses. Journal of Global Business and Economics, 2(1), 1-13.

Amran, N. A. (2011b). Who influence family company performance: founder of successor? Proceeding of the 2nd International Conference on Business and Economic Research, 1352-1361.

Amran, N. A., \& Ahmad, A. C. (2009). Family business, board dynamics and firm value: evidence from Malaysia. Journal of Financial Reporting \& Accounting, 7(1), 53-74. http://dx.doi.org/10.1108/19852510980000641

Bachkaniwala, D., Wright, M., \& Ram, M. (2001). Succession in South Asian family businesses in the UK. International Small Business Journal, 19(4), 15-27. http://dx.doi.org/10.1177/0266242601194001

Barach, J. A., \& Gantisky, J. B. (1995). Successful succession in family business. Family Business Review, 8(2), 131-155. http://dx.doi.org/10.1111/j.1741-6248.1995.00131.x

Bocatto, E. (2005). Family owned business (FOB) succession: The influence of pre-performance in the nomination of family and non-family members evidence from Spanish firms. Journal of Small Business Management, 48(4), 497-523. http://dx.doi.org/10.1111/j.1540-627X.2010.00306.x

Brenes, E. R., Madrigal, K., \& Requena, B. (2011). Corporate governance and family business performance. Journal of Business Research, 64, 280-285. http://dx.doi.org/10.1016/j.jbusres.2009.11.013

Carlock, R. S. (2010). When family businesses are best. Palgrave: MacMillan. http://dx.doi.org/10.1057/9780230294516

Carlock, R. S., \& Ward, J. L. (2001). Strategic planning for the family business. New York: Palgrave Macmillan.

Carlock, R. S., \& Ward, J. L. (2005). Assuring a healthy business: family business key issues. New York: Plagrave Macmillan. http://dx.doi.org/10.1057/9780230508750

Chua, J. H., Chrisman, J. J., \& Sharma, P. (2003). Succession and non succession concerns of family firms and agency relationship with nonfamily managers. Family Business Review, 16, 89. http://dx.doi.org/10.1111/j.1741-6248.2003.00089.x

Chua, J. H., Chrisman, J. J., \& Steier, L. P. (2003). Extending the theoretical horizons of family business research. Entrepreneurship Theory and Practice, 27(4), 331-338. http://dx.doi.org/10.1111/1540-8520.00012

Claessens, S., Djankov, S., \& Lang, L. H. P. (2000). The separation of ownership and control in East Asian $\begin{array}{lllll}\text { corporation. Journal of Finance and Economic, } & \text { 58, }\end{array}$ http://dx.doi.org/10.1016/S0304-405X(00)00067-2

Coleman, \& Greig. (2009). Family business succession planning: a plain English guide to. business, family \& property law. New South Wales: Solicitos and Notaries.

Davis, P. S., \& Harveston, P. D. (2001). The phenomenon of substantive conflict in the family firm: A cross-generational study. Journal of Small Business Management, 39(1), 14-30. http://dx.doi.org/10.1111/0447-2778.00003

Demers, J. (2003). Succession planning in SMEs: studies confirm that the future of family-owned business is at risk. CMA Management December/January 2003: 12-13.

Deraman, N., Mohamad, A., Bakar, H., Hashim, N., \& Keat, O. Y. (2010). Keusahawanan teori dan praktis. Ed. Ke-2. Kuala Lumpur: Mc Graw Hill.

Dickson, P. H., Solomon, G. T., \& Weaver, K. M. (2008). Entrepreneurial selection and success: does education matter? Journal of Small Business and Enterprise Development, 15(2), 239. http://dx.doi.org/10.1108/14626000810871655

Dyck, B., Mauws, M., Starke, F. A., \& Mischke, G. A. (2002). Passing the baton: the importance of sequence, timing, technique, and communication in executive succession. Journal of Business Venturing, 17, 143-162. http://dx.doi.org/10.1016/S0883-9026(00)00056-2 
Gomez, E. T. (2005). Inter-ethnic relations, business and identity: the Chinese in Britain and Malaysia. United Nations Research Institute for Social Development. Identities, Conflict and Cohesion Programme September.

Handler, W. C. (1990). Succession in family firms; a mutual role adjustment between entrepreneur and next-generation family members. Entrepreneurship Theory and Practices, 15, 37-51.

Handler, W. C. (1994). Succession in family business: a review of the research. Family Business Review, 7(2), 133-157. http://dx.doi.org/10.1111/j.1741-6248.1994.00133.x

Ibrahim, A. B., Soufani, K., \& Lam, J. (2001). A study of succession in a family firm. Family Business Review, 14(3), 245-258. http://dx.doi.org/10.1111/j.1741-6248.2001.00245.x

Ip, B., \& Jacobs, G. (2006). Business succession planning: a review of the evidence. Journal of Small Business Development, 13(3), 326-350. http://dx.doi.org/10.1108/14626000610680235

Ismail, N., \& Mahfodz, A. N. (2009). Succession planning in family firms and its implication on business performance. Journal of Asia Entrepreneurship and Sustainability, 5(3).

Jasani, N. K. (2002). Malaysia's family businesses: The Family \& The Business International Survey Report. Shamsir Jasani Grant Thorton \& Malaysian Institute of Management.

Kohar, U. H. A. (2010). Factor Influencing the sustainability of Malaysian Bumiputera New Technology-Based Small Firms.

Krejcie, R. V., \& Morgan, D. M. (1970). Dlm Chua Yan Piaw. 2006. Kaedah dan statistik penyelidikan: kaedah penyelidikan. Buku 1 hlm 186. Kuala Lumpur: McGraw Hill.

Kuratko, D. F., \& Hodgetts, R. M. (2006). Entrepreneurship theory, process and practice. South-Western: Thomson Learning.

Lam, J. (2009). Succession process in a large Canadian family business: a longitudinal case study of the Molson family business: 1786-2007. Tesis PhD. Concordia University Montreal, Quebec, Canada.

Le Breton-Miller, I., Miller, D., \& Steier, L. P. (2004). Toward an integrative model of effective FOB succession. Entrepreneurship Theory and Practice, 28, 305-328. http://dx.doi.org/10.1111/j.1540-6520.2004.00047.x

Longenecter, J. G., Moore, C. W., \& Petty, J. W. (2005). Small business management: an entrepreneurial emphasis. Ed. Ke12. South-Western: Thomson Learning.

Luk, S. T. K. (1996). Success in Hong Kong: factors self-reported by successful small business owners. Journal of Small Business Management, 34(3), 68-74.

Mahenthran, H. (2010). Financial management knowledge among Malay family-owned business (MFOBS) entrepreneurs. The First International Development Cenference of Syria 2010, 1-50.

Masuo, D., Fong, G., Yanagida, J., \& Cabal, C. (2001). Factors associated with business and family success: a comparison of single manager and dual manager family business households. Journal of Family Economic, 22, 55-73. http://dx.doi.org/10.1023/A:1009492604067

McCann, J. E. III., Leon-Guerrero, A. Y., \& Haley, J. D. J. (2001). Strategic goals and practices of innovative family business. Journal of Small Business Management, 39(1), 50-59. http://dx.doi.org/10.1111/0447-2778.00005

McConaughy, D. L. (2000). Family CEOs vs. nonfamily CEOs in the family-controlled firm: An examination of the level and sensitivity of pay to performance. Family Business Review, 13(2), 121-131. http://dx.doi.org/10.1111/j.1741-6248.2000.00121.x

Morris, H. M., Williams, R. O., Allen, J. A., \& Avila, R. A. (1997). Correlates of success in family business transitions. Journal of Business Venturing, 12, 385-401. http://dx.doi.org/10.1016/S0883-9026(97)00010-4

Morris, H. M., Williams, R., \& Nel, D. (1996). Factors influencing family business succession. International Journal of Entrepreneurial Behaviour \& Research, 2(3), 68-81. http://dx.doi.org/10.1108/13552559610153261

Ngui, C. Y. K. (2002). Asian Family Businesses: From Riches to Rags? Malaysian Business, 2, 27.

Nunnally, J., \& Bernstein. (1994). Psychometrictheory. Ed. Ke-3. New York: McGraw Hill.

Palaniappan, A. K. (2009). Research and SPSS (PASW). Petaling Jaya: Prentice Hall.

Pallant, J. (2007). SPSS survival manual: A step by guide to data analysis using SPSS third edition. New South 
West: Allen \& Unwin.

Parrish, S. (2009, May). Successfully transferring the family business: a new methodology. Journal of Financial Service Professionals, 47-55.

Phan, P. H., Butler. J. E., \& Lee. S. H. (2005). Corporate Governance and management succession in family business. First Haniel Foundation Entrepreneuship and Management Conference, Berlin, Germany.

Picard, D. (2004). Business transition: a literature review. Canadian Federation of Independent Business.

Poza, E. J, (2004). Family business. Mason. Oh: Thompson.

Pyromalis, V. D., \& Vozikis, G. S. (2009). Mapping the successful succession process in family firms: evidence from Greece. International Entrepneurship Management Journal, 5, 439-460. http://dx.doi.org/10.1007/s11365-009-0118-3

Pyromalis, V. D., Vozikis, G. S., Kalkanteras, T. A., Rogdaki, M. E., \& Sigalas, G. P. (2006). An integrated framework for testing the success of the family business succession process according to gender specificity. In P. Z. Poutziouris, K. X. Smyrnios, \& S. B. Klein (Eds.), Handbook of research on family business (pp. 422-442). Northampton: Edward Elgar.

Reijonen, H., \& Kommpula, R. (2007). Perception of success and its effect on small firm performance. Journal of Small Business and Enterprise Development, 14(4), 689-701. http://dx.doi.org/10.1108/14626000710832776

Robinson, P. B., \& Sexton, E. A. (1994). The effect of education and experience on self-employment success. Journal of Business Venturing, 9(5), 141-156. http://dx.doi.org/10.1016/0883-9026(94)90006-X

Sardeshmukh, S. R. (2008). Successor development in family firms. Tesis Sarjana, Rensselaer Polytechnic Institute. Troy, New York.

Sareshmukh, S. R., \& Corbett, A. C. (2011). The duality of internal and external development of successors: opportunity recognition in family firms. Family Business Review, 24, 111-125. http://dx.doi.org/10.1177/0894486510391783

Schulze, W. S., Lubatkin, M. H., \& Dino, R. N. (2003). Exploring the agency consequences of ownership dispersion among inside directors at family firms. Academy of Management Journal, 46, 179-194. http://dx.doi.org/10.2307/30040613

Shah, S. (2006). Critical success factors for Indian family owned business in Kenya. Integrative Business Research Project Master, University Of Pretoria.

Sharma, P., Chrisman, J. J., \& Chua, J. H. (2003). Predictors of satisfaction with the succession process in family firms. Journal of Business Venturing, 18, 667-687. http://dx.doi.org/10.1016/S0883-9026(03)00015-6

Sharma, P., Chrisman, J. J., Pablo, A. L., \& Chua, J. H. (2001). Determinants of initial satisfaction with the succession process in family firms: a conceptual model. Entrepreneurship Theory and Practice, 25(3), 17-35.

Shung, Y. K. (2006). Factors influencing family business succession among family-owned small business firms in Kota Kinabalu, Sabah. Kertas Projek Sarjana, Open University Malaysia (OUM).

Sigalas, C. R., Chondrakis, G., Zaharopoulos, A., \& Vozikis, G. S. (2008). Performance lags and gaps during family business succession: The dual inefficiency of succession discontinuity and lower intial postsuccession performance. In P. H. Phan, \& J. H. Butler (Eds.), Theoretical developments and future research in family business (pp. 231-260). North Carolina: Information Age Publishing, Inc.

SME Corporation Malaysia. (2011). Laporan Kaji Selidik Suku pertama tahun 2011. Retrieved from http://www.smecorp.gov.my

Smyrnios, K. X., \& Dana, L. (2006). The MGI Australian family and private business survey 2006.

Song, M., Podoynitsyna, K., Bij, H., \& Halman, J. L. M. (2008). Success factors in new venture: a meta-analysis. Journal of Product Management, 25(1), 7-27. http://dx.doi.org/10.1111/j.1540-5885.2007.00280.x

Sreih, F., Djoundourian, J., \& Salpie. (2008). Correlates of longevity: A regression model. Journal of Business and Entrepreneurship, 20(1).

Sundaramurthy, C. (2008). Sustaining trust within family businesses. Family Business Review, 21(1), 89-102. http://dx.doi.org/10.1111/j.1741-6248.2007.00110.x 
Ucbasaran, D., Westhead, P., Wright, M., \& Flores, M. (2010). The nature of entrepreneurial experience, business failure and comparative optimism. Journal of Venturing, 25, 541-555. http://dx.doi.org/10.1016/j.jbusvent.2009.04.001

Venter, E., Boshoff, C., \& Maas, G. (2005). The influence of successor-related factors on the succession process in small and medium-sized family businesses. Family Business Review, 18, 283-303. http://dx.doi.org/10.1111/j.1741-6248.2005.00049.x

Voithofer, P., \& Mandl, I. (2004). Transfer and succession in Austrian family firms. KMU Forschung Austria. Austrian Institute for SME Research.

Wang, Y. (2002). Pass the baton within the family - a case study on succession issues. Working Paper Series 2002, Wolverhampton Business School the Management Research Centre.

Wang, Y., Watkins, D., Harris, N., \& Spicer, K. (2004). The relationship between succession issues and business performance: evidence from UK family SMEs. International Journal of Entrepreneurial Behaviour \& Research, 10(1-2), 59-84. http://dx.doi.org/10.1108/13552550410521380

White, W., Krinke, T., \& Geller, D. (2004). Family business succession planning: Devising an overall strategy. Journal of Financial Service Professionals, 58(3), 67-86.

Zahra, S. A., \& Sharma, P. (2004). Family business research: a strategic reflection. Family Business Review, 17(4), 331-346. http://dx.doi.org/10.1111/j.1741-6248.2004.00022.x

Zakaria, N. (2007). Perniagaan keluarga. In R. Mahmood (Ed.), Prinsip-prinsip keusahawanan. Singapore: Thomson Learning.

\section{Copyrights}

Copyright for this article is retained by the author(s), with first publication rights granted to the journal.

This is an open-access article distributed under the terms and conditions of the Creative Commons Attribution license (http://creativecommons.org/licenses/by/3.0/). 